\title{
Historic records of organic compounds from a high Alpine glacier: influences of biomass burning, anthropogenic emissions, and dust transport
}

\author{
C. Müller-Tautges ${ }^{1}$, A. Eichler ${ }^{2,3}$, M. Schwikowski ${ }^{2,3,4}$, G. B. Pezzatti ${ }^{5}$, M. Conedera ${ }^{5}$, and T. Hoffmann ${ }^{1}$ \\ ${ }^{1}$ Institute of Inorganic Chemistry and Analytical Chemistry, Johannes Gutenberg University of Mainz, Mainz, Germany \\ ${ }^{2}$ Laboratory of Radiochemistry and Environmental Chemistry, Paul Scherrer Institute, Villigen, Switzerland \\ ${ }^{3}$ Oeschger Centre for Climate Research, University of Bern, Bern, Switzerland \\ ${ }^{4}$ Department for Chemistry and Biochemistry, University of Bern, Bern, Switzerland \\ ${ }^{5}$ Insubric Ecosystems Research Group, Swiss Federal Institute for Forest, Snow and Landscape Research WSL, \\ Bellinzona, Switzerland
}

Correspondence to: T. Hoffmann (t.hoffmann@ uni-mainz.de)

Received: 13 April 2015 - Published in Atmos. Chem. Phys. Discuss.: 13 May 2015

Revised: 27 September 2015 - Accepted: 4 January 2016 - Published: 28 January 2016

\begin{abstract}
Historic records of $\alpha$-dicarbonyls (glyoxal, methylglyoxal), carboxylic acids $\left(\mathrm{C}_{6}-\mathrm{C}_{12}\right.$ dicarboxylic acids, pinic acid, $p$-hydroxybenzoic acid, phthalic acid, 4methylphthalic acid), and ions (oxalate, formate, calcium) were determined with annual resolution in an ice core from Grenzgletscher in the southern Swiss Alps, covering the time period from 1942 to 1993. Chemical analysis of the organic compounds was conducted using ultra-high-performance liquid chromatography (UHPLC) coupled to electrospray ionization high-resolution mass spectrometry (ESI-HRMS) for dicarbonyls and long-chain carboxylic acids and ion chromatography for short-chain carboxylates. Long-term records of the carboxylic acids and dicarbonyls, as well as their source apportionment, are reported for western Europe. This is the first study comprising long-term trends of dicarbonyls and long-chain dicarboxylic acids $\left(\mathrm{C}_{6}-\mathrm{C}_{12}\right)$ in Alpine precipitation. Source assignment of the organic species present in the ice core was performed using principal component analysis. Our results suggest biomass burning, anthropogenic emissions, and transport of mineral dust to be the main parameters influencing the concentration of organic compounds. Ice core records of several highly correlated compounds (e.g., $p$-hydroxybenzoic acid, pinic acid, pimelic, and suberic acids) can be related to the forest fire history in southern Switzerland. $P$-hydroxybenzoic acid was found to be the best organic fire tracer in the study area, revealing the
\end{abstract}

highest correlation with the burned area from fires. Historical records of methylglyoxal, phthalic acid, and dicarboxylic acids adipic acid, sebacic acid, and dodecanedioic acid are comparable with that of anthropogenic emissions of volatile organic compounds (VOCs). The small organic acids, oxalic acid and formic acid, are both highly correlated with calcium, suggesting their records to be affected by changing mineral dust transport to the drilling site.

\section{Introduction}

To place recent environmental and climatic changes in a longer-term context, and to disentangle anthropogenic and natural sources of air pollution, information on past atmospheric conditions is necessary. Glaciers are valuable environmental archives, as they preserve past atmospheric aerosol deposited with snowfall. Hence, the analysis of aerosol-related chemical compounds in ice core samples can give information on past environmental and climatic conditions. Most studies have focused on inorganic aerosol-related parameters such as $\mathrm{NH}_{4}^{+}, \mathrm{NO}_{3}^{-}$, and $\mathrm{SO}_{4}^{2-}$, as well as black carbon and heavy metals, for which a significant increase was observed in snow during the twentieth century (Preunkert et al., 2001, 2003; Schwikowski et al., 1999; Mayewski et al., 1986; Fischer et al., 1998a, b; Döscher et al., 1996; Legrand 
et al., 2002; Eichler et al., 2000a; van de Velde et al., 2000; Barbante et al., 2004; Schwikowski et al., 2004; Gabrielli et al., 2005). This was mainly assigned to enhanced anthropogenic emissions of the respective precursors, e.g., enhanced anthropogenic $\mathrm{SO}_{2}$ emissions, resulting in high sulfate concentrations archived in ice.

In contrast to the well-established analysis of inorganic species, organic compounds have been analyzed in ice cores to a much smaller extent (Legrand et al., 2013). These compounds, however, play an important role as constituents of secondary organic aerosol (SOA), which is a major part of atmospheric aerosol. Generally, carboxylic acids are one of the most abundant groups of water-soluble organics in the atmosphere (e.g., Legrand et al., 2007). Concentrations of monocarboxylic acids, mainly formic acid and acetic acid, have been determined in ice cores from the Alps (Legrand et al., 2003), Greenland (Legrand et al., 1992; Legrand and de Angelis, 1996), and Antarctica (de Angelis et al., 2012). These compounds can be attributed to vegetation emission, boreal forest fires, or anthropogenic (vehicle) emissions. Short dicarboxylates $\left(\mathrm{C}_{2}-\mathrm{C}_{5}\right)$ were analyzed in distinct sections of Alpine firn and ice cores from Col du Dôme and Colle Gnifetti. They were attributed to secondary formation from vegetation emissions (Legrand et al., 2007). Historic records of dicarboxylic acids $\left(\mathrm{C}_{2}-\mathrm{C}_{10}\right)$, oxocarboxylic acids $\left(\mathrm{C}_{2}-\mathrm{C}_{9}\right)$, and $\alpha$-dicarbonyls $\left(\mathrm{C}_{2}-\mathrm{C}_{3}\right)$ were reported in an ice core from Greenland (Kawamura et al., 2001), suggesting dicarboxylic acids in ice cores to serve as proxies for the oxidative capacity of the atmosphere in the past. Longchain carboxylic acids (fatty acids, $\mathrm{C}_{14}-\mathrm{C}_{22}$ ) were also detected in an ice core from Greenland and attributed to marine and terrestrial biological sources (Kawamura et al., 1996). Formaldehyde was analyzed in a firn core from Lys Glacier (Largiuni, 2003) and ice cores from Greenland (Staffelbach et al., 1991), but there are indications that it is not well preserved under most conditions (Hutterli et al., 2002). Some studies focus on persistent organic pollutants (Pavlova et al., 2014; Wang et al., 2008; Lacorte et al., 2009; Villa et al., 2006) and polycyclic aromatic hydrocarbons in ice cores (Gabrieli et al., 2010). Humic-like substances (HULIS) were also analyzed in an Alpine ice cores (Guilhermet et al., 2013; Legrand et al., 2007). The concentration of organic carbon in the Alpine region was reported to have doubled since the middle of the twentieth century, which was assigned to an enhanced oxidative capacity of the atmosphere, resulting in increased production of secondary organic aerosol (Legrand et al., 2007). Only recently, a study comprising the analysis of organic compounds formaldehyde, short-chain $\left(\mathrm{C}_{1}-\mathrm{C}_{5}\right)$ mono- and dicarboxylates, HULIS, dissolved organic carbon, and water-insoluble organic carbon revealed a rather unexpected increase in water-soluble organic aerosol by a factor of 3 since the 1950s, which was attributed mainly to an increase in biogenic emissions (Preunkert and Legrand, 2013). Legrand et al. (2013) also reported the trend of water-soluble organic carbon including $\mathrm{C}_{2}-\mathrm{C}_{5}$ dicarboxylic acids in an

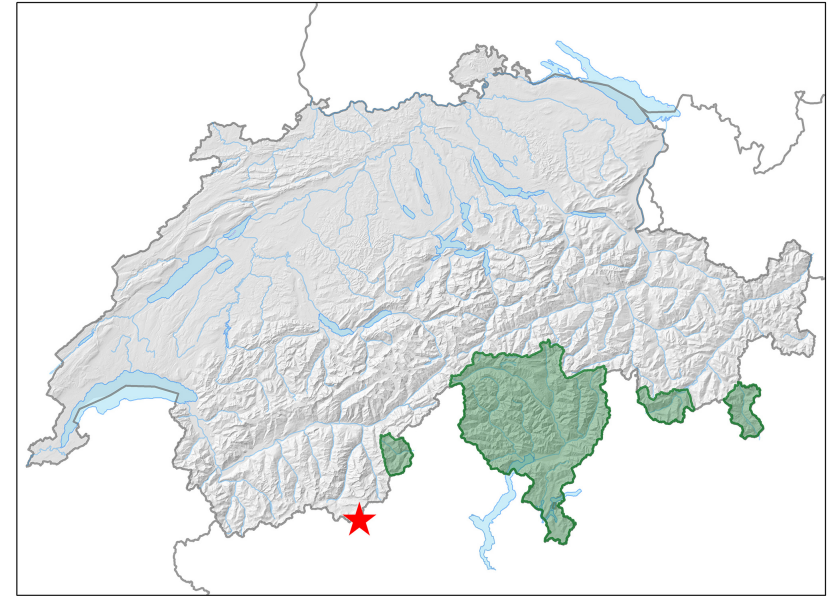

Figure 1. Map of Switzerland (MeteoSwiss, 2015); the drilling site at the Grenzgletscher (red star) and the area of the southern Swiss Alps (green) used to extract fire events are indicated.

Alpine ice core to be influenced to a greater extent by natural than by anthropogenic sources. The two smallest alphadicarbonyls, glyoxal and methylglyoxal, are final products of the oxidation chain of many volatile organic compounds (VOCs). They have received increasing scientific interest in recent years due to their important role in the formation and growth of SOA (Fu et al., 2008). However, no data on the long-term trend of these compounds have been available for the Alpine area so far.

Cold glaciers from mid-latitude mountain areas, such as the Alps, serve as an excellent archive of regional shortlived air pollution, covering a time span of decades to centuries. In this work, an array of organic compounds reported to be important constituents of SOA were analyzed in a well-characterized ice core from Grenzgletscher (Monte Rosa Massif) in the southern Swiss Alps. Here we present the first long-term records of $\alpha$-dicarbonyls (glyoxal, methylglyoxal) and carboxylic acids $\left(\mathrm{C}_{6}-\mathrm{C}_{10}\right.$ and $\mathrm{C}_{12}$ dicarboxylic acids, pinic acid, $p$-hydroxybenzoic acid, phthalic acid, 4methylphthalic acid, and vanillic acid) in the Alpine region, covering the period 1942-1993. Source apportionment of the investigated organic species was performed to evaluate the influence of biogenic emissions, forest fires, as well as anthropogenic emissions on past aerosol composition in western Europe.

\section{Experimental/material and methods}

\subsection{Field site and sampling}

The samples analyzed in this work originate from a $125 \mathrm{~m}$ long ice core recovered in 1994 from the Grenzgletscher located in the Monte Rosa massif in the southern Swiss Alps near the Italian border ( $4200 \mathrm{~m}$ a.s.l.; $45^{\circ} 55^{\prime} \mathrm{N}, 7^{\circ} 52^{\prime} \mathrm{E}$, see 
Fig. 1) (Eichler et al., 2000b). The drilling site is characterized by a high annual net accumulation rate of $2.7 \mathrm{~m}$ w.e. Using radar sounding, the glacier thickness at the drilling site was estimated to be approximately $190 \mathrm{~m}$ with a relatively flat glacier geometry (slope of about $10^{\circ}$ ), revealing the suitability of the upper Grenzgletscher to serve as an environmental archive. The drilling was performed using an electromechanical drill with an inner diameter of $7.8 \mathrm{~cm}$. Two hundred and forty ice core sections were recovered, each 50 $80 \mathrm{~cm}$ long. The ice core sections were packed in polyethylene bags in the field and kept at $-25^{\circ} \mathrm{C}$ during transport and storage. The ice core covers the period 1937-1994 (see Eichler et al., 2000b, for details on the ice core dating). Dating accuracy is \pm 2 years for the time before 1970 and \pm 1 year for the period of 1970-1993.

Samples were cut out from the ice core sections at $-20^{\circ} \mathrm{C}$ in a cold room at the PSI in Villigen, Switzerland, using a modified band saw (stainless steel blades, tabletop and saw guides covered with PTFE). All surfaces of the cutting devices the ice came into contact with were cleaned with ethanol before and after cutting each ice core section to prevent cross-contamination. To reduce potential contamination from drilling, transport, or storage, the outer layer (about $0.5 \mathrm{~cm}$ ) of each ice core section was removed with the band saw. To obtain annual averages, equal aliquots of the ice sections belonging to a certain year (two to nine sections per year) were combined in a pre-cleaned glass jar, resulting in a final sample mass of $215-410 \mathrm{~g}$. The jars were closed tightly using screw caps with PTFE-coated septa and kept frozen until analysis. Fifty-one samples were prepared, covering the years 1942-1993 (with the exception of 1969, due to poor ice quality). Ultrapure water was frozen to obtain procedural blank samples, which were treated like real ice core samples to correct for possible contamination from sample preparation and analysis.

\subsection{Chemical analysis}

The analysis of $\alpha$-dicarbonyls glyoxal (G) and methylglyoxal (MG) was performed based on a method by Müller-Tautges et al. (2014) using a sample weight of 75-85 g. Measurements were conducted using ultra-high-performance liquid chromatography (UHPLC) coupled to electrospray ionization high-resolution mass spectrometry (ESI-HRMS). The adapted method is described in the Supplement. Monocarboxylic acids (vanillic acid (VAN), $p$-hydroxybenzoic acid $(\mathrm{PHB})$ ) and dicarboxylic acids (adipic acid $\left(\mathrm{C}_{6}\right)$, pimelic acid $\left(\mathrm{C}_{7}\right)$, suberic acid $\left(\mathrm{C}_{8}\right)$, azelaic acid $\left(\mathrm{C}_{9}\right)$, sebacic acid $\left(\mathrm{C}_{10}\right)$, dodecanedioic acid $\left(\mathrm{C}_{12}\right)$, methylphthalic acid (MPH), pinic acid (PIN), phthalic acid (PHT)) were analyzed using solid phase extraction (SPE) with strong anion exchange, followed by derivatization (esterification) and UHPLC-ESIHRMS. The measurements were conducted using the same UHPLC-HRMS system as described above. A detailed de-

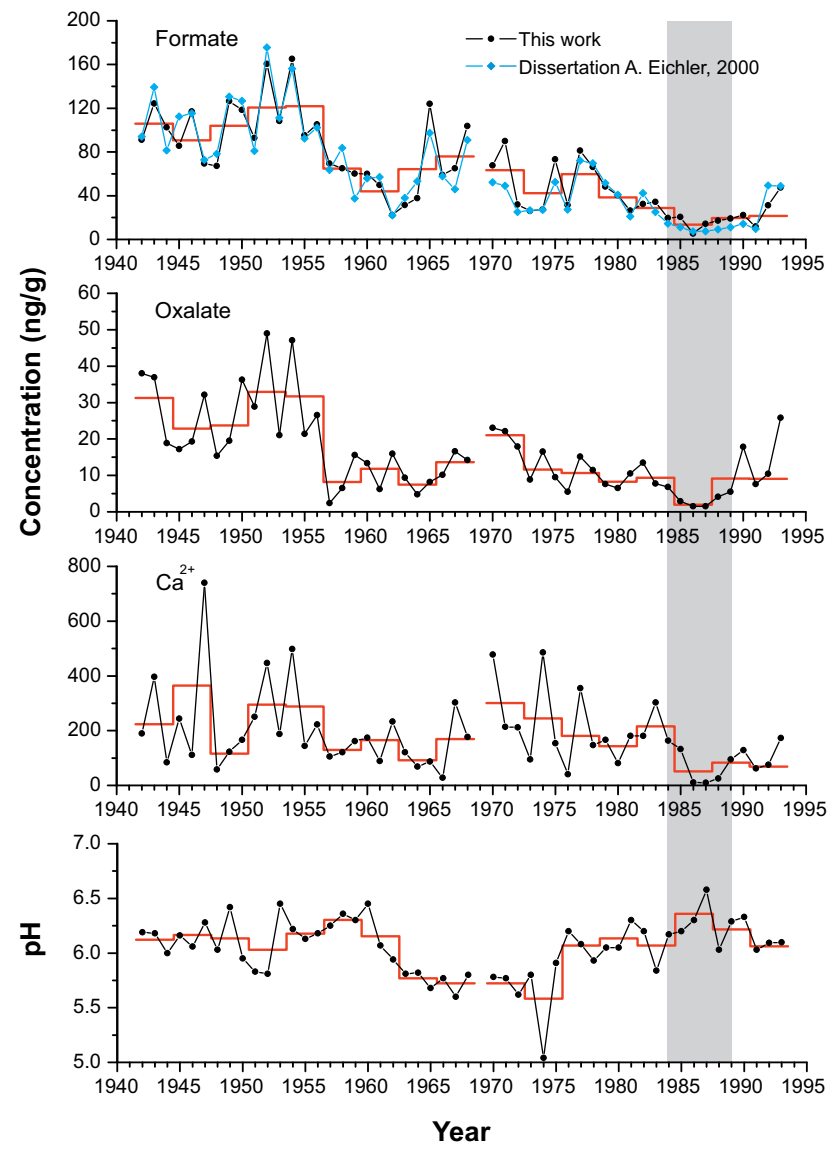

Figure 2. Ice core records of oxalate, formate, calcium, and $\mathrm{pH}$ (black dots: annual averages, red line: 3 -year averages). The period influenced by meltwater (1984-89) is marked in gray. The ice core record of formate obtained from previous high-resolution measurements (blue diamonds, annual averages based on 2148 measurements, Eichler, 2000) fits well with the record determined using the 1 -year sampling strategy.

scription of the SPE process as well as derivatization and analysis is given in the Supplement.

Concentrations of the small carboxylates formate (FOR) and oxalate (OXA), as well the concentration of calcium $\left(\mathrm{Ca}^{2+}\right)$ in the 51 annual samples were determined using ion chromatography (Metrohm 850 Professional IC combined with a 872 Extension Module and a 858 Professional Sample Processor autosampler). The $\mathrm{pH}$ was determined using an 8103 Orion $^{\mathrm{TM}}$ Electrode coupled to a Metrohm pH meter 605.

\subsection{Calculations of the burned area from historical forest fires in southern Switzerland}

Forest fire data for southern Switzerland (hereafter FSS) were gathered from the Swissfire database (Pezzatti et al., 2010) by extracting the fire events which occurred during the study period in the southern Swiss Alps. This region comprises the area of Zwischbergen-Gondo in the canton 
Table 1. Limits of detection (LOD) and obtained concentrations of dicarboxylic acids, monocarboxylic acids, $\alpha$-dicarbonyls, and Ca ${ }^{2+}$ analyzed in the Grenzgletscher ice core (BDL refers to below detection limit).

\begin{tabular}{|c|c|c|c|c|c|}
\hline & \multirow[b]{2}{*}{ Abbreviation (Cn) } & \multirow[b]{2}{*}{ LOD $\left(\operatorname{ng~g}^{-1}\right)$} & \multicolumn{3}{|c|}{ Concentration $\left(\mathrm{ng} \mathrm{g}^{-1}\right)$} \\
\hline & & & Average & Minimum & Maximum \\
\hline \multicolumn{6}{|l|}{ Dicarboxylic acids } \\
\hline Adipic acid & $\mathrm{C}_{6}$ & 0.001 & 0.52 & BDL & 2.4 \\
\hline Pimelic acid & $\mathrm{C}_{7}$ & 0.0007 & 0.15 & BDL & 0.86 \\
\hline Suberic acid & $\mathrm{C}_{8}$ & 0.0002 & 0.099 & BDL & 0.44 \\
\hline Azelaic acid & $\mathrm{C}_{9}$ & 0.0002 & 0.12 & BDL & 0.45 \\
\hline Sebacic acid & $\mathrm{C}_{10}$ & 0.0002 & 0.029 & 0.002 & 0.11 \\
\hline Dodecanedioic acid & $\mathrm{C}_{12}$ & 0.005 & 0.022 & BDL & 0.11 \\
\hline Pinic acid & PIN & 0.0003 & 0.22 & BDL & 0.92 \\
\hline Phthalic acid & PHT & 0.004 & 0.099 & BDL & 0.47 \\
\hline 4-methylphthalic acid & $\mathrm{MPH}$ & 0.0003 & 0.029 & BDL & 0.22 \\
\hline \multicolumn{6}{|c|}{ Monocarboxylic acids/carboxylates } \\
\hline Vanillic acid & VAN & 0.021 & 0.067 & BDL & 0.36 \\
\hline$p$-hydroxybenzoic acid & PHB & 0.009 & 0.021 & BDL & 0.15 \\
\hline Formate & FOR & 0.8 & 64 & 5 & 165 \\
\hline Oxalate & OXA & 0.8 & 15.9 & 1.5 & 49 \\
\hline \multicolumn{6}{|l|}{$\alpha$-Dicarbonyl compounds } \\
\hline Glyoxal & $\mathrm{G}$ & 0.003 & 0.38 & BDL & 1.8 \\
\hline Methylglyoxal & MG & 0.003 & 0.046 & BDL & 0.27 \\
\hline \multicolumn{6}{|l|}{ Ions } \\
\hline Calcium & $\mathrm{Ca}^{2+}$ & 0.9 & 186 & 10 & 740 \\
\hline
\end{tabular}

of Valais, the whole canton Ticino, and the valleys Misox, Bergell, and Puschlav in the canton of Grisons (see Fig. 1). For each recorded event, the burned area was grouped in vegetation cover types (grassland, softwood, and hardwood) relevant for the resulting emissions of organic components. When details on the forest composition were missing (ca. $2 \%$ of the fire events), the softwood to hardwood proportion of the burned forest area was calculated by overlaying the burned area perimeter with forest stand maps (events which occurred from 1969 onwards) or estimated based on the available information, namely the location and altitude of the ignition point and main tree species hit by the event.

\section{Results and discussion}

Ice core records covering the period from 1942 to 1993 were obtained for nine dicarboxylic acids $\left(\mathrm{C}_{6}-\mathrm{C}_{10}\right.$, $\mathrm{C}_{12}$, methylphthalic acid, pinic acid, and phthalic acid), two monocarboxylic acids (vanillic and $p$-hydroxybenzoic acids), two $\alpha$-dicarbonyls (glyoxal and methylglyoxal), and ions (calcium $\left(\mathrm{Ca}^{2+}\right)$, formate, and oxalate).

To evaluate if the applied annual sampling strategy was representative of the assigned years, the newly established annual record of formate was compared to an already existing high-resolution record (comprising 2148 distinct samples, Eichler, 2000, see Fig. 2). The records obtained by 1-year sampling and 1-year averaging of the high-resolution data show excellent agreement (correlation coefficient $r=0.954$, $p<0.001)$, revealing that the sampling was representative of the distinct years.

\subsection{Concentrations of the organic compounds}

The concentration range and average concentrations of the compounds detected in the ice core are presented in Table 1. The most abundant organic compound detected in the ice core was formate with an average concentration of $64 \mathrm{ng} \mathrm{g}^{-1}$, followed by oxalate, adipic acid, glyoxal, and pinic acid, with $15.9,0.52,0.38$, and $0.22 \mathrm{ng} \mathrm{g}^{-1}$, respectively. There are only few studies reporting concentration records of monoand dicarboxylic acids as well as $\alpha$-dicarbonyls in ice cores (see Table 2). The average concentration of formate determined in this work is in the same range as reported in glaciers from Siberian Altai (period 1250-2001 AD, mean concentration $89 \mathrm{ng} \mathrm{g}^{-1}$, Eichler et al., 2009), Col du Dôme, 1925-1995, $80 \mathrm{ng} \mathrm{g}^{-1}$, Legrand et al., 2003), and Tianshan (1981-1998, 102.8 $\mathrm{ng} \mathrm{g}^{-1}$, Li et al., 2001), yet about 2 times lower than measured in an ice core from the Tibetan Plateau (1983-1999, 186.6 ng g ${ }^{-1}$, Wang, 2004). The concentration 


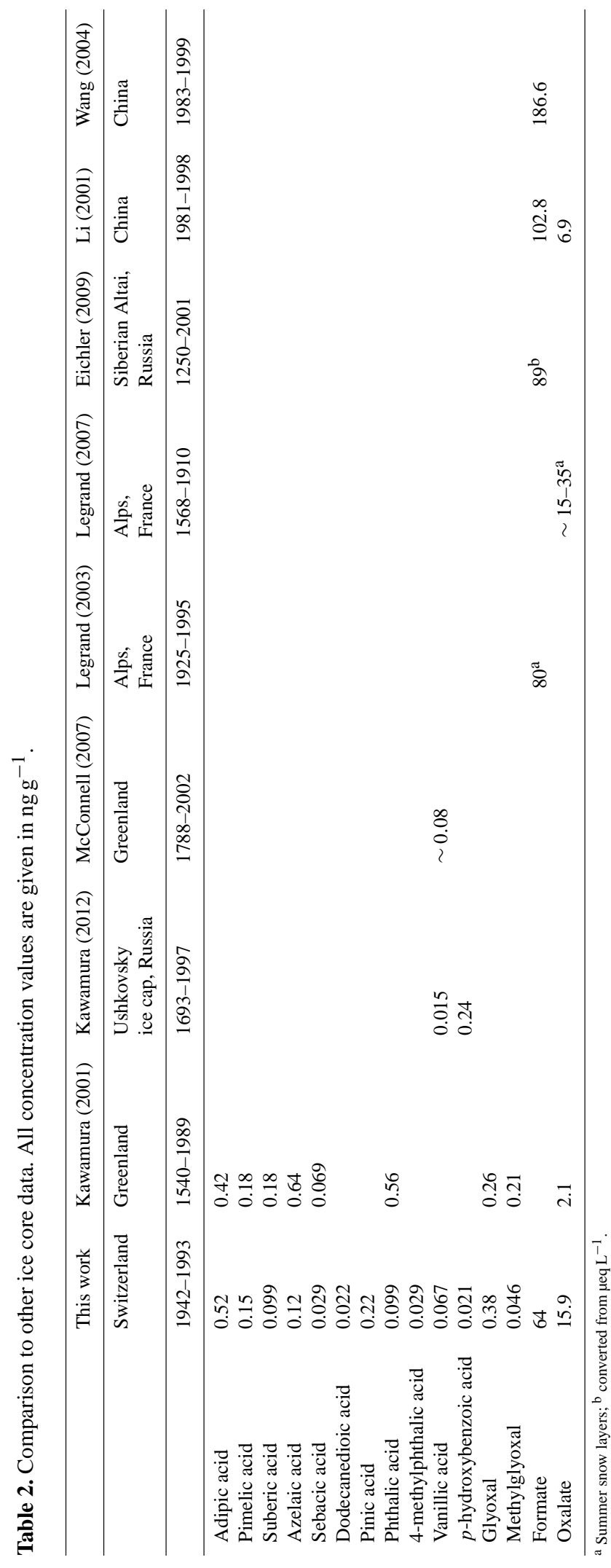

of oxalate in the Grenzgletscher ice core ranges from 1.5 to $49 \mathrm{ng} \mathrm{g}^{-1}$, with an average concentration of $15.9 \mathrm{ng} \mathrm{g}^{-1}$. These values are about 2 times higher than the concentration of oxalate in the glacier from Tianshan, China (Li et al., 2001) and about 7 times higher than those reported in a study from Greenland (Kawamura et al., 2001), the latter comprising the analysis of dicarboxylic acids and $\alpha$-dicarbonyls between 1540 and 1989. The observed concentration ranges of $\mathrm{C}_{6}-\mathrm{C}_{10}$ dicarboxylic acids in the Grenzgletscher ice core are comparable to those reported in the Greenland ice core by Kawamura et al. (2001), with the exception of azelaic acid. Concentrations of azelaic acid determined in this work (below detection limit, BDL-0.45 $\mathrm{ng} \mathrm{g}^{-1}$, average $0.12 \mathrm{ng} \mathrm{g}^{-1}$ ) were about 5 times lower than in the Greenland ice core (<0.06-2.38 $\mathrm{ng} \mathrm{g}^{-1}$, average $0.64 \mathrm{ng} \mathrm{g}^{-1}$ ). Phthalic acid concentrations in the Grenzgletscher ranged between BDL and $0.47 \mathrm{ng} \mathrm{g}^{-1}$ with an average value of $0.099 \mathrm{ng} \mathrm{g}^{-1}$, which is also about 5 times lower than measured in the Greenland ice core. Dodecanedioic acid and methylphthalic acid have not been reported in ice cores yet. Their concentrations in the Grenzgletscher ice core were found to be comparable to that of sebacic acid, with an average value of 0.022 and $0.029 \mathrm{ng} \mathrm{g}^{-1}$, for dodecanedioic acid and methylphthalic acid, respectively.

Pinic acid has not yet been reported in ice cores either. Its concentration in the Grenzgletscher core is $0.22 \mathrm{ng} \mathrm{g}^{-1}$ on average, ranging from BDL to $0.92 \mathrm{ng} \mathrm{g}^{-1}$. These values are comparable to those detected for pimelic acid. Average concentrations of glyoxal and methylglyoxal were $0.38 \mathrm{ng} \mathrm{g}^{-1}$ (ranging from BDL to $1.76 \mathrm{ng} \mathrm{g}^{-1}$ ) and $0.046 \mathrm{ng} \mathrm{g}^{-1}$ (BDL-0.27 $\left.\mathrm{ng} \mathrm{g}^{-1}\right)$, respectively. The mean concentration of methylglyoxal is about 8 times lower than that of G. Concentration records of glyoxal and methylglyoxal in ice cores have only been reported for Greenland (Kawamura et al., 2001), although they are ubiquitous compounds in atmospheric aerosols and precipitation. The results obtained for glyoxal are comparable to the concentrations found by Kawamura et al. (2001) (0.023$1.14 \mathrm{ng} \mathrm{g}^{-1}$, average $0.26 \mathrm{ng} \mathrm{g}^{-1}$ ), whereas methylglyoxal concentrations determined in this work are much lower than reported in the Greenland ice core (0.031-1.36 $\mathrm{ng} \mathrm{g}^{-1}$, average $0.21 \mathrm{ng} \mathrm{g}^{-1}$ ).

Concentrations of vanillic acid ranged from below detection limit (BDL), which is $0.021-0.36 \mathrm{ng} \mathrm{g}^{-1}$, with an average value of $0.067 \mathrm{ng} \mathrm{g}^{-1}$. These concentrations are in the same range as reported in an ice core from Greenland (0.01$0.125 \mathrm{ng} \mathrm{g}^{-1}$, McConnell et al., 2007) and Ushkovsky ice cap in Northeast Asia (BDL-0.13 ng g ${ }^{-1}$, Kawamura et al., 2012). The concentration of $p$-hydroxybenzoic acid ranged from BDL (0.0087) to $0.151 \mathrm{ng} \mathrm{g}^{-1}$, with an average concentration of $0.021 \mathrm{ng} \mathrm{g}^{-1}$. Compared to the study by Kawamura et al. (2012) from the Ushkovsky ice cap, which is the only study reporting $p$-hydroxybenzoic acid in ice cores, our results are about 10 times lower. Furthermore, the average concentration of $p$-hydroxybenzoic acid is about 3 


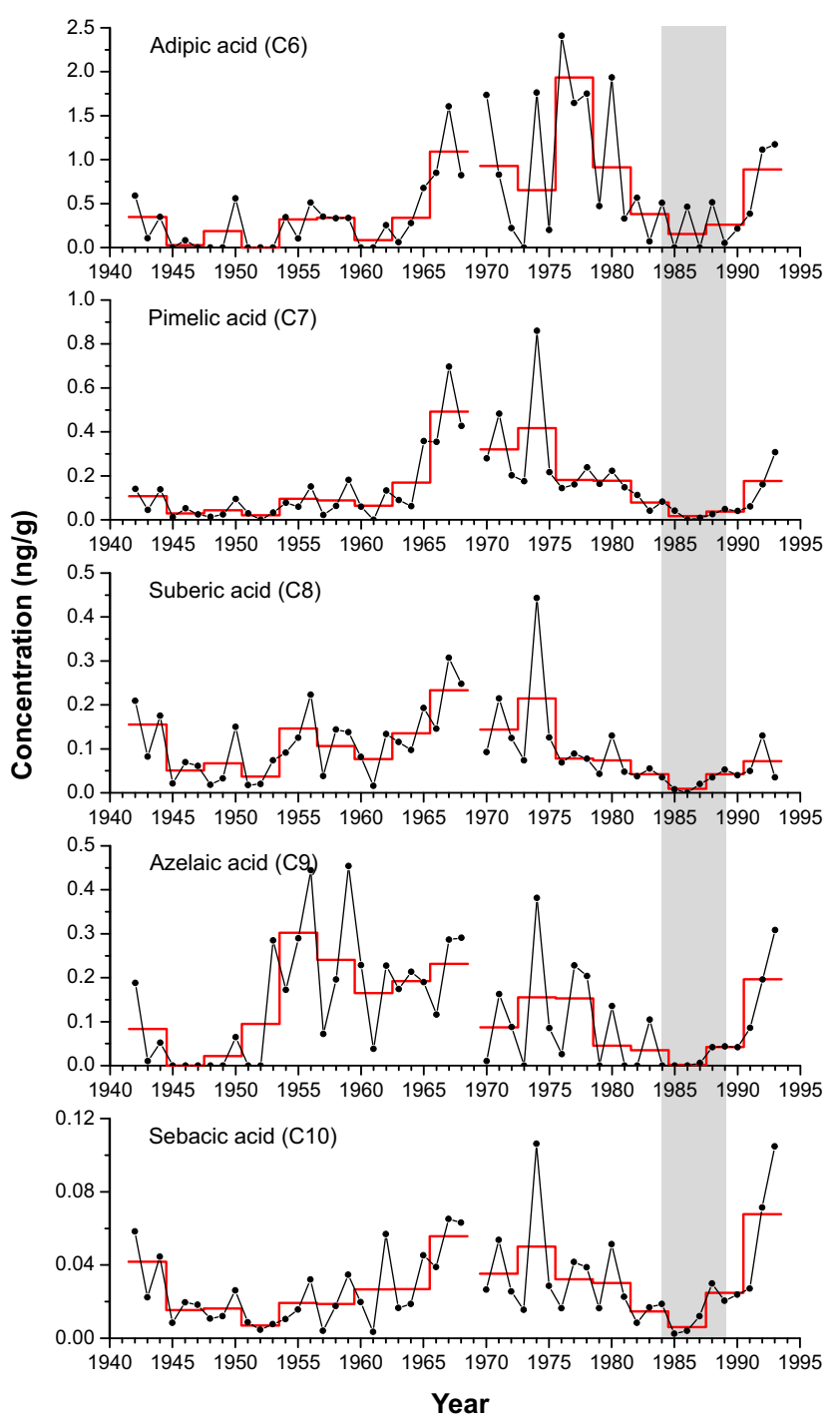

Figure 3. Ice core records of dicarboxylic acids $\mathrm{C}_{6}-\mathrm{C}_{10}$ in the Alpine ice core from upper Grenzgletscher (black dots: annual averages, red line: 3-year averages). The period influenced by meltwater (1984-89) is marked in gray.

times lower than that of vanillic acid, whereas Kawamura et al. (2012) reported concentrations of $p$-hydroxybenzoic acid in the Ushkovsky ice core to be 16 times higher than that of vanillic acid. Such differences are likely to result from distinctions in sources and atmospheric transport of organic aerosol to the respective glacier site.

\subsection{Historic records}

The historic records obtained for the (di)carboxylic acids and $\alpha$-dicarbonyls are shown in Figs. 2-5. Three-year averages were calculated to compensate for year-to-year fluctuations of the aerosol transport to the glacier site (analogous to Schwikowski et al., 2004). All the obtained records, based on 3-year averages, exhibit fluctuations of about 1 order of

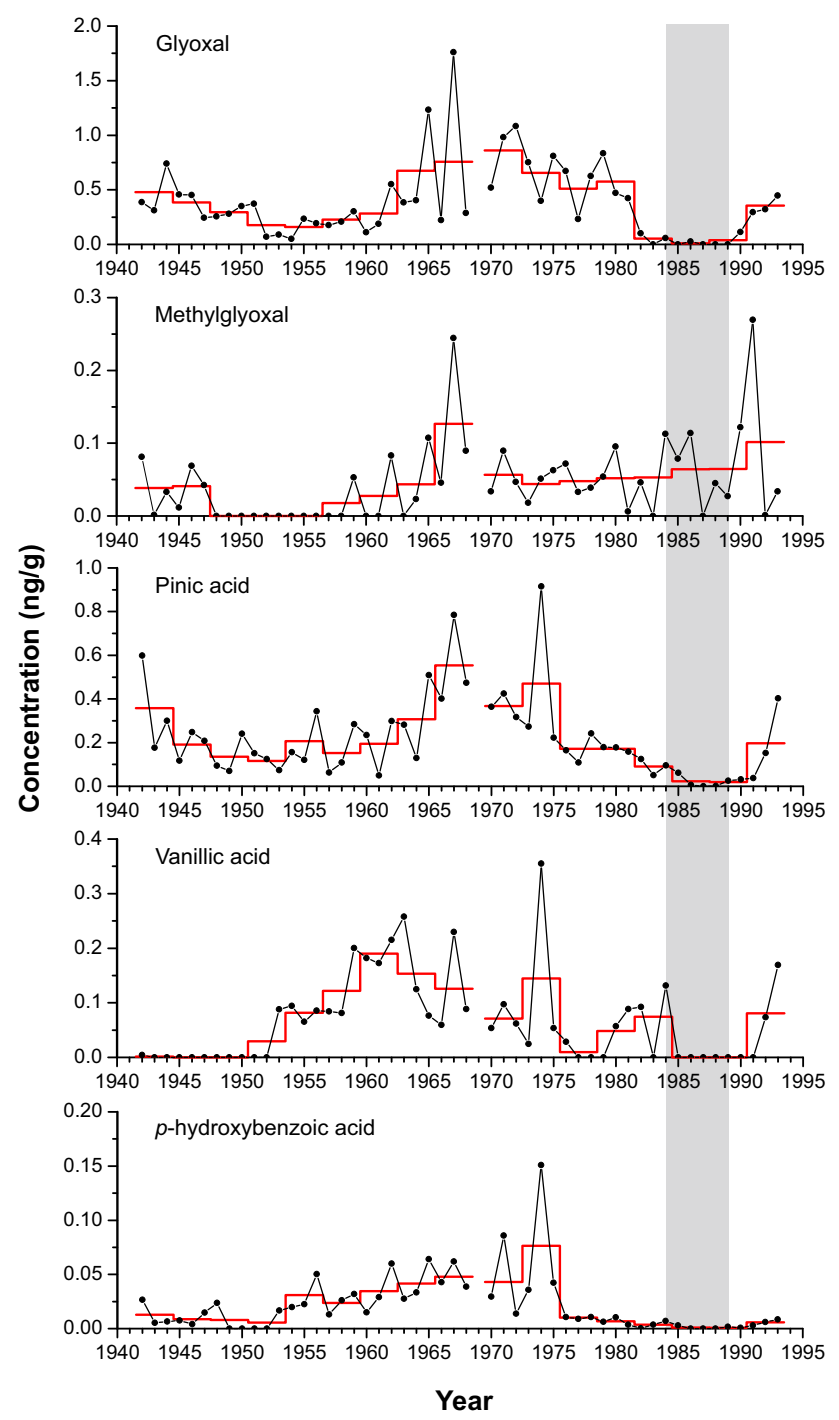

Figure 4. Ice core records of $\alpha$-dicarbonyls (glyoxal and methylglyoxal), pinic acid, and monocarboxylic acids (vanillic and $p$ hydroxybenzoic acid) in the Alpine ice core from upper Grenzgletscher (black dots: annual averages, red line: 3-year averages). The period influenced by meltwater (1984-89) is marked in gray.

magnitude in concentration during the investigated time period. Concentration maxima of formate and oxalate occurred during the 1940s and beginning of the 1950s. This is different for all other organic compounds, revealing minimum concentration before the 1950 s, followed by an increase in concentration starting in about 1950-1955. Depending on the individual compound, the maximum concentrations are reached around 1955 (e.g., azelaic acid), 1960 (e.g., vanillic acid), between 1965 and 1970 (e.g., pinic acid), during the late 1970s (e.g., adipic acid, $p$-hydroxybenzoic acid), or at the beginning of the 1990s (e.g., methylglyoxal). During the period from 1984 to 1989, the concentrations of all compounds (except for methylglyoxal) dropped to levels close to 


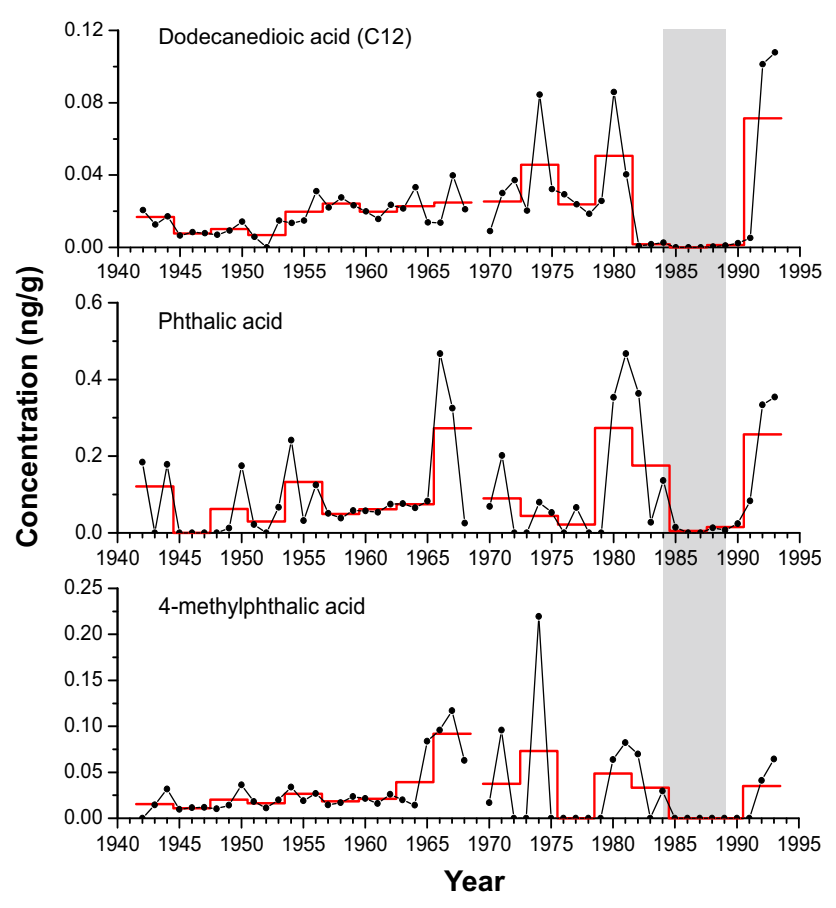

Figure 5. Ice core records of dicarboxylic acids (dodecanedioic acid, phthalic acid, and methylphthalic acid) in the Alpine ice core from upper Grenzgletscher (black dots: annual averages, red line: 3 -year averages). The period influenced by meltwater (1984-89) is marked in gray.

the detection limit, before they increased again in the early 1990s. This sudden drop in concentration was also observed by Eichler et al. (2001) for certain ionic species detected in the same ice core and was attributed to the relocation of ions with meltwater in the firn section of the glacier. While the normal seasonal pattern of ions like $\mathrm{Cl}^{-}, \mathrm{F}^{-}, \mathrm{NO}_{3}^{-}$, and $\mathrm{NH}_{4}^{+}$ was preserved, the concentrations of $\mathrm{K}^{+}, \mathrm{Mg}^{2+}$, or $\mathrm{Ca}^{2+}$, for example, were significantly decreased. Eichler et al. (2001) suggested rearrangement processes during snow metamorphism in the ice to be the main reason for the fractionation of the ions. Depending on the solubility of an ionic compound in ice, it is located either inside the grain or at its surface. In the latter case, the ion is prone to be relocated by percolating water. As the possibility of being incorporated into the ice lattice is rather unlikely for the organic compounds detected in the ice core because of the molecule size, they are assumed to be located at the grain surfaces. The observed decrease in concentration during the period 1984-1989 can thus not be interpreted as an atmospheric signal, but is due to a post-depositional leaching of the organic species.

Interestingly, no significant decrease in concentration was detected for methylglyoxal. The ratio methylglyoxal/glyoxal is about 0.13 on average during the time not influenced by meltwater influx, yet rises up to 7 during the percolation period. This indicates a fractionation of glyoxal and methylglyoxal possibly caused by the leaching process.
Further post-depositional processes that may influence records of the organic species in the snowpack are aqueousphase oxidation, photochemistry, and remobilization after deposition and during firnification (Ervens et al., 2004; Grannas et al., 2007; Legrand et al., 2003). Aqueous-phase oxidation was reported for methylglyoxal by Ervens at al. (2004). Although there is only a limited aqueous phase present at the grain boundaries under the conditions at this site (ice temperature between -1 and $-9^{\circ} \mathrm{C}$ ), oxidation of methylglyoxal cannot be excluded as a possible reason for the generally low concentration of methylglyoxal in the glacier. Processes involving photochemistry or migration/evaporation of compounds are particularly important at sites with very low accumulation rates. Since the mean annual accumulation rate at the Grenzgletscher site is high ( 2.7 m.w.e.), the latter processes are assumed to have a minor effect on the concentration record presented here.

\subsection{Source assignment}

To investigate the main sources of the organic trace species, a principal component analysis (PCA) including Varimax rotation was performed. Three-year average values of the obtained records were used and the years affected by the meltwater influx removed from the record. Four principal components (PCs) were found to account for $82 \%$ of the data variance in total (see Table 3). High loadings (>0.65) of $p$ hydroxybenzoic acid, pinic acid, pimelic acid, suberic acid, glyoxal, and methylphthalic acid are observed in PC1, which explains $31.5 \%$ of the data variability. PC1 is correlated with the area burned by forest fires in southern Switzerland (FSS) and a major part (57\%) of the variance of $\mathrm{PC} 1$ is explained by the changes in FSS (Table 4). PC1 is therefore suggested to be linked to biomass burning.

The highest loadings within PC2 are observed for methylglyoxal, adipic acid, sebacic acid, dodecanedioic acid, and phthalic acid, indicating a link between these species. Indeed, the five compounds are significantly correlated (Fig. S1). As adipic acid and phthalic acid are reported to be mainly of anthropogenic origin (Hatakeyama et al., 1987; Koch et al., 2000; Zhang et al., 2010), this group may be influenced by anthropogenic emissions, explaining $24.4 \%$ of the data variability.

PC3 accounts for $16.3 \%$ of the data variability. It is dominated by high positive loadings of oxalate, formate, and $\mathrm{Ca}^{2+}$. As mineral dust originating mainly from the Sahara is the major source of $\mathrm{Ca}^{2+}$ being transported to the glacier, PC3 is a dust-related component.

PC4 explains $10.0 \%$ of the data variance and is dominated by high loadings of vanillic acid and azelaic acid, which are well correlated $(r=0.601, p=0.018)$. Vanillic acid is reported to be a conifer biomass burning marker, while azelaic acid is formed by the photo-oxidation of oleic acid, for example. Therefore, PC4 may have a mixed biomass burning and/or biogenic origin. 
Table 3. Loadings of the PCA with Varimax rotation performed on the normalized 3-year means and the variance explained by each component for the time period 1942-1993. Factor loadings $>|0.4|$ are shown. High loadings are indicated in bold.

\begin{tabular}{lrrrr}
\hline & \multicolumn{5}{c}{ Components } \\
\cline { 2 - 5 } Variable & PC1 & PC2 & PC3 & PC4 \\
\hline$p$-hydroxybenzoic acid & $\mathbf{0 . 9 5}$ & & & \\
Pinic acid & $\mathbf{0 . 8 7}$ & 0.41 & & \\
Pimelic acid & $\mathbf{0 . 7 9}$ & 0.56 & & \\
Suberic acid & $\mathbf{0 . 8 5}$ & & & \\
Glyoxal & $\mathbf{0 . 7 0}$ & 0.46 & & \\
4-methylphthalic acid & $\mathbf{0 . 6 9}$ & 0.44 & & \\
FSS & $\mathbf{0 . 8 8}$ & & & \\
Methylglyoxal & & $\mathbf{0 . 8 4}$ & & \\
Adipic acid & & $\mathbf{0 . 6 9}$ & & \\
Sebacic acid & & $\mathbf{0 . 8 0}$ & & \\
Dodecanedioic acid & & $\mathbf{0 . 6 1}$ & -0.43 & \\
Phthalic acid & & $\mathbf{0 . 7 7}$ & $\mathbf{0 . 9 2}$ & \\
Oxalate & & & $\mathbf{0 . 9 0}$ & \\
Formate & & & $\mathbf{0 . 5 7}$ & \\
Ca ${ }^{2+}$ & 0.51 & & & \\
Vanillic acid & & & & \\
Azelaic acid & 31.5 & 24.4 & 16.3 & \\
Variance explained (\%) & Biomass & Anthropogenic & Transport with & Biogenic/burning? \\
& burning & emissions & mineral dust & \\
\hline
\end{tabular}

Table 4. Coefficients of determination $\left(r^{2}\right)$ for compounds and components linked to biomass burning $\left(r^{2}\right.$, significant at the 0.05 level marked in bold).

\begin{tabular}{lcccc}
\hline$r^{2}$ & FSS (area all fires) & Grassland & Softwood & Hardwood \\
\hline$p$-hydroxybenzoic acid & $\mathbf{0 . 7 5}$ & $\mathbf{0 . 7 3}$ & 0.17 & $\mathbf{0 . 6 9}$ \\
Pinic acid & $\mathbf{0 . 3 7}$ & $\mathbf{0 . 4 0}$ & 0.06 & $\mathbf{0 . 3 4}$ \\
Pimelic acid & $\mathbf{0 . 3 1}$ & $\mathbf{0 . 4 4}$ & 0.14 & $\mathbf{0 . 2 0}$ \\
Suberic acid & $\mathbf{0 . 4 1}$ & $\mathbf{0 . 3 9}$ & 0.08 & $\mathbf{0 . 3 9}$ \\
4-methylphthalic acid & $\mathbf{0 . 3 4}$ & $\mathbf{0 . 5 1}$ & 0.16 & $\mathbf{0 . 2 1}$ \\
Glyoxal & $\mathbf{0 . 2 2}$ & $\mathbf{0 . 2 9}$ & $\mathbf{0 . 2 4}$ & 0.13 \\
Vanillic acid & $\mathbf{0 . 2 7}$ & $\mathbf{0 . 3 6}$ & 0.04 & $\mathbf{0 . 2 1}$ \\
PC1 & $\mathbf{0 . 5 7}$ & $\mathbf{0 . 6 5}$ & 0.19 & $\mathbf{0 . 4 7}$ \\
PC4 & 0.17 & $\mathbf{0 . 2 2}$ & 0.02 & 0.13 \\
\hline
\end{tabular}

The records of all PCs are shown in Fig. 6. In addition, the underlying correlations of the PCA are visualized in a correlation matrix in the Supplement (Fig. S1).

The performed PCA suggests that the major sources influencing the organic composition of the ice core were (in order of decreasing importance) (i) biomass burning, (ii) anthropogenic emissions, (iii) mineral dust, and (iv) biomass burning/biogenic emission. In the following, these source assignments of organic species deposited at the Grenzgletscher are discussed in more detail.

\subsubsection{Biomass burning}

The main factor influencing the composition of organic species in the ice core from upper Grenzgletscher is suggested to be biomass burning. The record of the PC1 scores resulting from the PCA is in good agreement with the total burned area in southern Switzerland (FSS, see Fig. 6a). The main part of the burned species is hardwood forest, followed by grassland (Fig. 7b). Due to the fire selectivity in terms of burned forest types (Pezzatti et al., 2009; Bajocco et al., 2011), softwood only accounts for a small part of the total burned area in southern Switzerland.

$P$-hydroxybenzoic acid is a pyrolysis product of lignin, and was used as a biomass burning marker compound, es- 

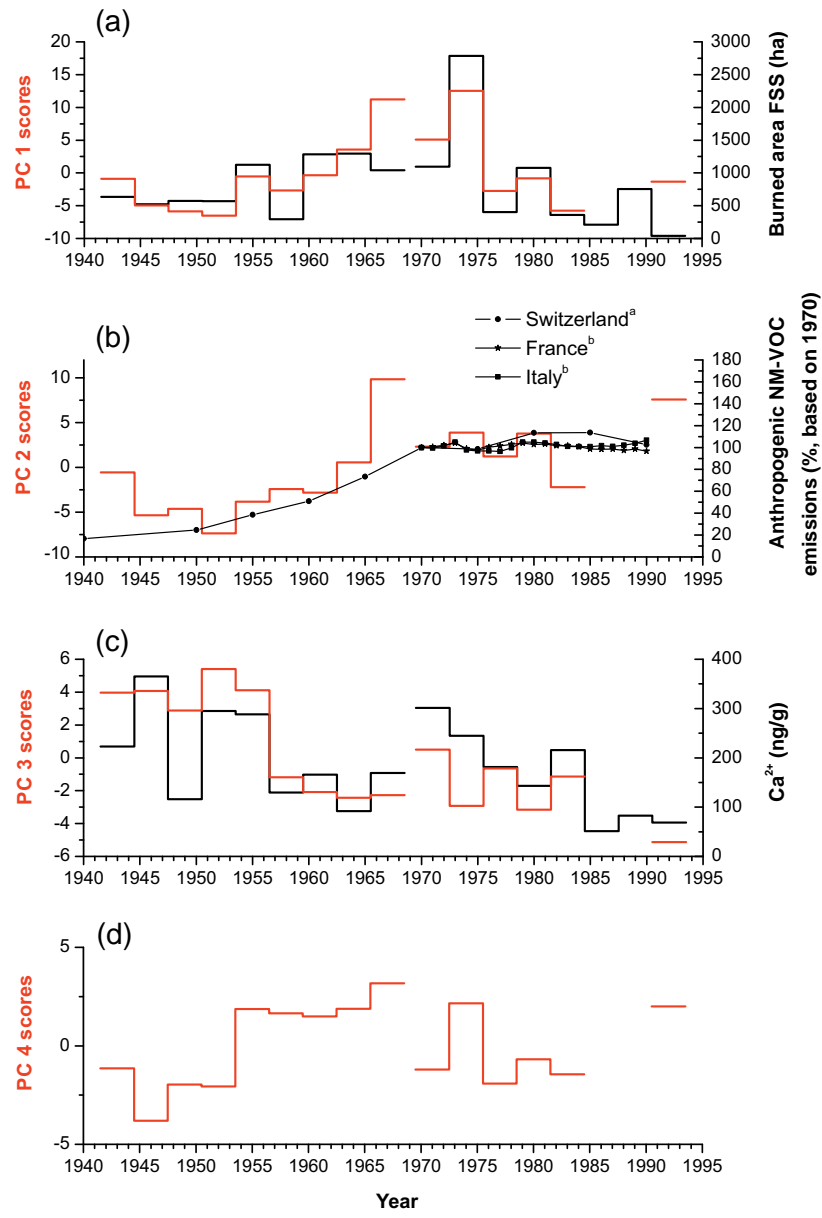

Figure 6. (a) Records of PC1 and FSS (burned area by fires in southern Switzerland), (b) PC2 and anthropogenic emissions of non-methane volatile organic compounds (NM-VOCs) in Switzerland, France, and Italy from 1940 to 1990, (c) PC3 and historic record of $\mathrm{Ca}^{2+}$, (d) PC4. Data in (b) were extracted from BUWAL (1995) and EDGAR (2010) (black symbols: annual averages, red/black line: 3-year averages). Records of the PC1-PC4 are given as $z$ scores (records normalized and scaled to a mean of 0 and a standard deviation of 1 ).

pecially resulting from incomplete combustion of grasses (Kawamura et al., 2012; Simoneit, 2002). The applicability as a fire marker is supported by our results, as $75 \%$ of the variance of $p$-hydroxybenzoic acid is explained by the changes in FSS in general. Furthermore, 73 and $69 \%$ of the variance is explained by the changes in burned grassland and hardwood areas, respectively (Table 4). However, as the burned grassland and hardwood areas are correlated, a discrimination between these two sources is not possible.

Pinic acid is found to exhibit a good correlation $(r=$ $0.609, p=0.016)$ with FSS and a strong correlation $(r=$ $0.864, p<0.01$ ) with the biomass burning marker compound $p$-hydroxybenzoic acid, both indicating biomass burning to be a major source for pinic acid deposited at the glacier.
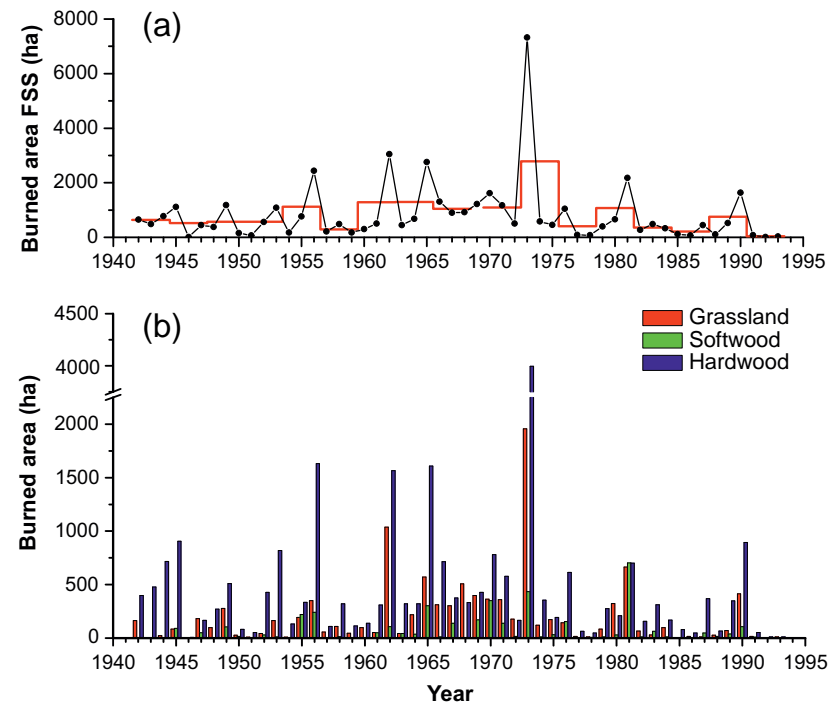

Figure 7. (a) Record of the burned area by fires in southern Switzerland (FSS; black dots: annual averages, red line: 3-year averages), (b) annual burned area of grassland, softwood, and hardwood in southern Switzerland from 1942 to 1993.

This was not expected so far, since pinic acid is unlikely to be emitted directly through biomass burning, as it is formed in the atmosphere as an oxidation product of biogenic VOCs. However, its precursors, $\alpha$ - and $\beta$-pinene, are formed and emitted by a wide range of plant species, especially monoterpene-storing conifers, like Scots pine ( $p i$ nus sylvestris L.) (Bäck et al., 2012), and to a minor extent also deciduous trees (e.g., European beech, fagus sylvatica L., Dindorf et al., 2006; or English oak, quercus robur L., Pérez-Rial et al., 2009), which are both Fagaceae, similar to the deciduous oaks and chestnut trees that dominate southern Switzerland. Indeed, several studies report enhanced emissions of $\alpha$ - and $\beta$-pinene through biomass burning (Kahnt et al., 2013; Simpson et al., 2011; Cheng et al., 2011; Lee et al., 2005). Pinenes are emitted from the burning trees, provided that not all of the emitted terpenes are oxidized in the flames. Emissions from smoldering are generally found to be higher than from flaming (Lee et al., 2005). As the emission rate of $\alpha$-pinene increases exponentially with temperature (Janson, 1993; Martin et al., 1999; Komenda, 2002), one could also assume that the heat wave associated with forest fires may cause enhanced emission of terpenes from the surrounding trees. The formation of pinonic acid associated with wood burning was reported by Cheng et al. (2011); hence, the formation of pinic acid in wood-burning plumes is also likely, as both pinonic acid and pinic acid are major products of pinene oxidation (Hoffmann et al., 1998; O'Dowd et al., 2002; Yu et al., 1999). In addition to the described enhanced emission of precursors, a second factor leading to high concentrations of pinic acid in connection with biomass burning might generally be the presence of a higher aerosol concentration. As 
biomass burning is a source of primary particles, the increase in particle matter might lead to enhanced partitioning of the newly formed pinic acid into the particle phase, preventing its further degradation. Pinic acid is often used as a marker for biogenic emissions. However, the results of this study indicate that the concentration of pinic acid detected in the ice core from Grenzgletscher is dominated by biomass burning origin and not by direct biogenic emission of the respective precursors. A further argument that the trend of pinic acid in the Grenzgletscher is influenced by biomass burning instead of direct biogenic emissions is the missing link to temperature. Direct biogenic emissions from forests have been shown to follow temperatures (Eichler et al., 2009; Kellerhals et al., 2010). Temperatures in southern Switzerland in the period 1940-1993 are high during the 1940s, 1980s, and 1990s, but lowest during the periods with the highest pinic acid concentrations (1960s and 1970s) (MeteoSwiss, 2015).

Pimelic acid, suberic acid, and methylphthalic acid have not been described in the literature in connection to biomass burning so far. Suberic acid is reported to be formed by the photo-oxidation of unsaturated fatty acids (Stephanou and Stratigakis, 1993). The strong correlation observed for suberic acid and pimelic acid $(r=0.831, p<0.001)$ suggests pimelic acid to be produced either by the same source as suberic acid, or by further oxidation of suberic acid, yielding dicarboxylic acids with lower carbon number. As much as $31-41 \%$ of the variance of these compounds is explained by the changes in FSS (Table 4).

Glyoxal is a secondary oxidation product formed from biogenic as well as anthropogenic precursors (e.g., toluene emitted from car exhaust) but has also been reported as a primary emission product by biomass burning, as indicated by the high loadings within PC1 and PC2. Glyoxal is significantly correlated with the burned area in southern Switzerland and $22 \%$ of the data variability in the glyoxal record is explained by fire-induced changes, increasing to $29 \%$ considering only grassland fires (Table 4).

In addition to the six species described above, vanillic acid is also loading partly on PC1. Vanillic acid is used as a marker for biomass burning as it is predominantly emitted by biomass burning processes. It is a pyrolysis product of lignin and is primarily associated with conifer species (Kawamura et al., 2012; McConnell et al., 2007). The vanillic acid record exhibits a significant correlation to $p$-hydroxybenzoic acid $(r=0.694, p=0.004), \mathrm{FSS}$, and azelaic acid $(r=0.524$ and $0.601, p=0.045$ and 0.018 , respectively). Although $27 \%$ of the data variability of vanillic acid is explained by changes in the burned area (FSS), the variability explained by changes in burned softwood area is negligible. Therefore, the applicability of vanillic acid as a fire marker especially for softwood (conifers) cannot be confirmed in the region of southern Switzerland, where hardwood forest and grasses are the dominant vegetation types hit by forest fires, especially in the main spring fire season (Pezzatti et al., 2009).
A strong concentration maximum of many organic compounds is observed in the year 1974. Within the limits of dating accuracy ( \pm 1 year in the period 1970-1993), the observed concentration maximum might be assigned to biomass burning aerosol from the historic fire season in 1973. In this particular year, the burned area in southern Switzerland reached a century maximum of about 7300 ha, which is 10 times the mean annual area burned between 1942 and 1993 (see Fig. 7a).

Besides biomass burning, organic species with a high loading in PC1 are also known to be emitted during domestic wood burning (see e.g., Gaeggeler et al., 2008). However, residential heating strongly peaks in winter and is restricted to urban areas at low altitudes. In winter, due to the stability of the atmosphere, pollution is trapped in the boundary layer close to the surface and does not affect the highaltitude Grenzgletscher site within the free troposphere. Forest fires in southern Switzerland peak in spring, especially during days with warm Foehn wind that causes a drop in both fuel moisture and air humidity (de Angelis et al., 2015). In such weather and atmospheric conditions, thermally driven convection enables the transport of the organic aerosols from forest fires to the glacier. Furthermore, energy consumption by wood burning in Switzerland peaked during the 1940s and from the 1980s on (Schweizerische Gesamtenergiestatistik, 2012). This is in contrast to the records of fire tracers (e.g., $p$-hydroxybenzoic acid) showing a maximum in the 1970s. In conclusion, we assume that the record of PC1 and thus the organic biomass burning tracers at the Grenzgletscher site are dominated by emissions from forest fires, but not by domestic wood burning.

\subsubsection{Anthropogenic emissions}

The second PC reveals the emission of anthropogenic VOCs to be an important source of organic species detected in the ice core, which is consistent with the sampling site being located in proximity to several highly industrialized countries in central Europe. The compounds exhibiting high loadings in PC2 are methylglyoxal, phthalic acid, adipic acid, sebacic acid, and dodecanedioic acid. Phthalic acid has been reported to be mainly formed by the photo-oxidation of anthropogenic emissions, such as polycyclic aromatic hydrocarbons and phthalates (Kautzman et al., 2010), whereas a minor part can also be attributed to primary emissions by biomass burning and vehicle exhaust (Zhang et al., 2010). One major source for methylglyoxal is toluene emission from cars (Nishino et al., 2010), dominating VOC emissions from traffic exhaust at many sites in Switzerland (Stemmler et al., 2005). Both dicarboxylic acids, sebacic acid and dodecanedioic acid, are correlated to phthalic acid $(r=0.545$, $p=0.036$ and $r=0.519, p=0.047$, respectively), indicating similar anthropogenic sources. Adipic acid has also been reported to be of anthropogenic origin (Grosjean et al., 1978). The PC2 score is in good agreement with the emission record 
of non-methane VOCs in Switzerland from 1940 to 1990 (Fig. 6b). Both PC2 scores and VOC emissions in Switzerland show an increase from the 1940s to 1970; afterwards they remain on an almost constant level. For France and Italy, data are only available starting from 1970. Like for Switzerland, the emissions from both countries do not change significantly from 1970 to 1990 . Actually, this trend is also indicated in the ice core records, as the maximum concentration levels of major VOC oxidation products phthalic acid, adipic acid, and dodecanedioic acid are found to occur only in the late 1970 s to early 1980 s, and the concentrations are still high in the early 1990s.

As already mentioned in Sect. 3.3.1, there is glyoxal loading both in PC1 and PC2, indicating mixed sources. Glyoxal (and methylglyoxal) is formed by the oxidation of VOCs emitted by cars (e.g., toluene). Glyoxal concentrations in the glacier show an increase starting in the 1950s and reach their maximum in the 1970s. This trend is consistent with enhanced road traffic emissions in the second half of the twentieth century.

\subsubsection{Mineral dust}

Major sources of the low-chain carboxylates formate and oxalate in the Alps are biogenic emissions (see e.g., Legrand et al., 2013). The observed high correlations between oxalate, formate, and $\mathrm{Ca}^{2+}$ suggest that their records are mainly determined by the common transport with mineral dust to the glacier, but not by the source. The historic records observed for these compounds are shown in Fig. 2. The scores of PC3 are in good agreement with the record of $\mathrm{Ca}^{2+}$, which serves as a marker for mineral dust (see Fig. 6c). Oxalate and formate are taken up by the alkaline mineral dust during transport mainly from the Sahara to the glacier by acid-base reaction. Larger (di)carboxylic acids are not found to be correlated to $\mathrm{Ca}^{2+}$. This could be explained by the relatively high acidity and volatility of the small acids, oxalate and formate, compared to their larger homologues. The known Saharan dustfall of 1949 is visible in both the records of $\mathrm{Ca}^{2+}$ and oxalate, but not in the record of formate. Therefore, sources of oxalate and formate might be similar but not identical over the whole time period covered by the ice core. An alternative explanation for the link of oxalate to mineral dust containing $\mathrm{Ca}^{2+}$ is the stabilization of oxalate due to the formation of calcium oxalate, thus preventing photo-induced decomposition of oxalate ions (which is reported to occur in the presence of iron oxides; see Rodríguez et al., 2009; Kim et al., 2010).

The strong relation between $\mathrm{Ca}^{2+}$ and oxalate was also observed from another Alpine ice core (Col du Dôme, Mt. Blanc). At this site, $\mathrm{Ca}^{2+}$ (dust) maxima were found between 1950 and 1960 (Preunkert and Legrand, 2013). Similarly, oxalate peaked in the 1950s (Legrand et al., 2007). A further factor that might influence formate (and to a lesser extent oxalate) concentrations in the atmosphere is the acidity $(\mathrm{pH})$.
Generally, a stronger acidification of the cloud water leads to a less efficient scavenging of the weak acid $\mathrm{HCOOH}$. Periods of enhanced $\mathrm{SO}_{2}$ and $\mathrm{NO}_{x}$ emissions have caused a decrease in ice core formate concentrations (see e.g., Legrand et al., 2003, Eichler et al., 2009, Legrand and de Angelis, 1996). Although at the Grenzgletscher site the formate and oxalate concentrations drop in the 1950s parallel with the acidification of the atmosphere, the increase of the $\mathrm{pH}$ after the 1970s did not lead to a rise in the concentrations of the weak short-chain acids (Fig. 2). While formate and oxalate are significantly correlated with $\mathrm{Ca}^{2+}(r=0.46$ and 0.63 , $p<0.05$, respectively), there is no significant correlation between formate/oxalate and $\mathrm{pH}(r=0.2$ and $0.17, p<0.05$, respectively). We conclude that the dust concentration of the air masses transported to the Grenzgletscher site is the dominating factor determining the uptake of formic and oxalic acid.

\subsubsection{Biomass burning/biogenic emissions}

We interpret PC4 (see Fig. 6d) as a component of mixed sources. This component with high loadings of vanillic acid and azelaic acid is partly explained by changes in the burned grassland area (22\%, see Table 4). The record of PC4 shows an early maximum around 1960, so does the burned area of grassland. However, since azelaic acid also has a high loading in PC4, this component may additionally be influenced by biogenic emissions, as azelaic acid is reported to be mainly formed by the photo-oxidation of unsaturated fatty acids (Stephanou and Stratigakis, 1993).

\section{Summary and conclusions}

For the first time, long-term measurements of organic trace components such as mono- and dicarboxylic acids and $\alpha$-dicarbonyls have been reported in an Alpine ice core from upper Grenzgletscher, Switzerland, covering the period 1942-1993. The characterization of aerosol in the ice concerning sources of organic compounds using PCA revealed four PCs to be responsible for $82 \%$ of the data variance in total, of which PC1-3 enabled source assignment of organic compounds detected in the ice core at trace levels.

Obtained concentration records of $p$-hydroxybenzoic acid, pinic acid, pimelic acid, suberic acid, glyoxal, and methylphthalic acid were shown to represent changes in the area affected by forest fires in southern Switzerland. Thus, biomass burning was found to be the main parameter influencing the composition of these organic compounds present in the ice. $P$-hydroxybenzoic acid showed the strongest correlation of all organic trace species with the total area burned by forest fires and correlated well with the burned area of grassland and hardwood. Thus, $p$-hydroxybenzoic acid can be used as a fire marker in the observed region. A connection of elevated concentrations of pimelic acid, suberic acid, methylphthalic 
acid, and pinic acid to increased biomass burning was shown for the first time. Pinic acid quantified in the ice core is suggested to be formed as a secondary oxidation product as a result of the enhanced emission of monoterpenes at elevated temperature during biomass burning. Although vanillic acid has been used as a typical marker for (softwood) burning before, no such correlation was observed in this study. This is explained by the high selectivity of hardwood and grass vegetation by forest fires in southern Switzerland.

Concentration trends of the organic compounds methylglyoxal, phthalic acid, adipic acid, sebacic acid, and dodecanedioic acid were found to represent changes in anthropogenic emissions. The anthropogenic emission of VOCs, leading to polar oxidation products being deposited at the glacier site, is therefore considered to be a second parameter influencing the composition of organic species in the ice.

These observations are in contrast to the results obtained for the small carboxylic acids oxalate and formate. A strong correlation of the most abundant organic compounds, oxalate and formate, was observed with $\mathrm{Ca}^{2+}$, indicating the uptake of small acids by alkaline and calcareous aerosol, and a common transport to the glacier. The concentration records of oxalate and formate are thus not determined by their source, but are mainly affected by changing dust transport to the drilling site. No such connection was detected for larger dicarboxylic acids.

\section{The Supplement related to this article is available online at doi:10.5194/acp-16-1029-2016-supplement.}

Acknowledgements. We thank T. Blunier, T. Döring, A. Döscher, V. Lavanchy, H. Rufli, and J. Schwader for their engagement in the field. We thank the two anonymous reviewers for their valuable and constructive comments.

Edited by: M. Schulz

\section{References}

Bäck, J., Aalto, J., Henriksson, M., Hakola, H., He, Q., and Boy, M.: Chemodiversity of a Scots pine stand and implications for terpene air concentrations, Biogeosciences, 9, 689-702, doi:10.5194/bg-9-689-2012, 2012.

Bajocco, S., Pezzatti, G. B., de Angelis, A., Conedera, M., and Ricotta, C.: Bootstrapping wildfire selectivity for the forest types of Canton Ticino (Switzerland), Earth Interact., 15, 1-11, doi:10.1175/2011EI387.1, 2011.

Barbante, C., Schwikowski, M., Döring, T., Gäggeler, H. W., Schotterer, U., Tobler, L., van de Velde, K., Ferrari, C., Cozzi, G., Turetta, A., Rosman, K., Bolshov, M., Capodaglio, G., Cescon, P., and Boutron, C.: Historical record of European emissions of heavy metals to the atmosphere since the 1650 s from
Alpine snow/ice cores drilled near Monte Rosa, Environ. Sci. Technol., 38, 4085-4090, doi:10.1021/es049759r, 2004.

BUWAL: Schriftenreihe Umwelt Nr. 256: Vom Menschen verursachte Luftschadstoff-Emissionen in der Schweiz von 1900 bis 2010, Bundesamt für Umwelt, Wald und Landschaft BUWAL, Bern, 1995.

Cheng, Y., Brook, J. R., Li, S.-M., and Leithead, A.: Seasonal variation in the biogenic secondary organic aerosol tracer cispinonic acid: enhancement due to emissions from regional and local biomass burning, Atmos. Environ., 45, 7105-7112, doi:10.1016/j.atmosenv.2011.09.036, 2011.

de Angelis, M., Traversi, R., and Udisti, R.: Long-term trends of mono-carboxylic acids in Antarctica: comparison of changes in sources and transport processes at the two EPICA deep drilling sites, Tellus B, 64, 573, doi:10.3402/tellusb.v64i0.17331, 2012.

de Angelis, A., Ricotta, C., Conedera, M., and Pezzatti, G. B.: Modelling the meteorological forest fire niche in heterogeneous pyrologic conditions, PLoS ONE, 10, e0116875, doi:10.1371/journal.pone.0116875, 2015.

Dindorf, T., Kuhn, U., Ganzeveld, L., Schebeske, G., Ciccioli, P., Holzke, C., Köble, R., Seufert, G., and Kesselmeier, J.: Significant light and temperature dependent monoterpene emissions from European beech (Fagus sylvatica L.) and their potential impact on the European volatile organic compound budget, J. Geophys. Res., 111, D16, doi:10.1029/2005JD006751, 2006.

Döscher, A., Gäggeler, H. W., Schotterer, U., and Schwikowski, M.: A historical record of ammonium concentrations from a glacier in the Alps, Geophys. Res. Lett., 23, 2741-2744, doi:10.1029/96GL02615, 1996.

EDGAR: Emission Database for Global Atmospheric Research (EDGAR), European Commission, Joint Research Centre (JRC)/PBL Netherlands Environmental Assessment Agency, release version 4.2, available at: http://edgar.jrc.ec.europa.eu/, last access: 28 April 2014, 2010.

Eichler, A.: Deposition von Spurenstoffen in Firn und Eis alpiner Gletscher, Untersuchung von Nord-Süd-Gradienten, Dissertation, University of Bern, Bern, 2000 (in German).

Eichler, A., Schwikowski, M., and Gäggeler, H. W.: An Alpine icecore record of anthropogenic $\mathrm{HF}$ and $\mathrm{HCl}$ emissions, Geophys. Res. Lett., 27, 3225-3228, doi:10.1029/2000GL012006, 2000a.

Eichler, A., Schwikowski, M., Gäggeler, H. W., Furrer, V., Synal, H.-A., Beer, J., Saurer, M., and Funk, M.: Glaciochemical dating of an ice core from upper Grenzgletscher (4200 ma.s.1.), J. Glaciol., 46, 507-515, doi:10.3189/172756500781833098, 2000 b.

Eichler, A., Schwikowski, M., and Gäggeler, H. W.: Meltwaterinduced relocation of chemical species in Alpine firn, Tellus B, 53, 192-203, doi:10.1034/j.1600-0889.2001.d01-15.x, 2001.

Eichler, A., Brütsch, S., Olivier, S., Papina, T., and Schwikowski, M.: A 750 year ice core record of past biogenic emissions from Siberian boreal forests, Geophys. Res. Lett., 36, L18813, doi:10.1029/2009GL038807, 2009.

Ervens, B., Feingold, G., Frost, G. J., and Kreidenweis, S. M.: A modeling study of aqueous phase production of dicarboxylic acids: 1. Chemical pathways and speciated organic mass production, J. Geophys. Res., 109, D15205, doi:10.1029/2003JD004387, 2004.

Fischer, H., Wagenbach, D., and Kipfstuhl, J.: Sulfate and nitrate firn concentrations on the Greenland ice sheet 1. Largescale ge- 
ographical deposition changes, J. Geophys. Res., 103, 2192721934, doi:10.1029/98JD01885, 1998a.

Fischer, H., Werner, M., Wagenbach, D., Schwager, M., Thorsteinnson, T., Wilhelms, F., Kipfstuhl, J., and Sommer, S.: Little Ice Age clearly recorded in northern Greenland ice cores, Geophys. Res. Lett., 25, 1749-1752, doi:10.1029/98GL01177, 1998b.

Fu, T., Jacob, D.,Wittrock, F., Burrows, J., Vrekoussis, M., and Henze, D.: Global budgets of atmospheric glyoxal and methylglyoxal, and implications for formation of secondary organic aerosols, J. Geophys. Res., 113, D15303, doi:10.1029/2007JD009505, 2008.

Gabrieli, J., Vallelonga, P., Cozzi, G., Gabrielli, P., Gambaro, A., Sigl, M., Decet, F., Schwikowski, M., Gäggeler, H., Boutron, C., Cescon, P., and Barbante, C.: Post 17th century changes of European PAH emissions recorded in high-altitude Alpine snow and ice, Environ. Sci. Technol., 44, 3260-3266, doi:10.1021/es903365s, 2010.

Gabrielli, P., Barbante, C., Boutron, C., Cozzi, G., Gaspari, V., Planchon, F., Ferrari, C., Turetta, C., Hong, S., and Cescon, P.: Variations in atmospheric trace elements in Dome C (East Antarctica) ice over the last two climatic cycles, Atmos. Environ., 39, 6420 6429, doi:10.1016/j.atmosenv.2005.07.025, 2005.

Gaeggeler, K., Prevot, A. S. H., Dommen, J., Legreid, G., Reimann, S., and Baltensperger, U.: Residential wood burning in an Alpine valley as a source for oxygenated volatile organic compounds, hydrocarbons and organic acids, Atmos. Environ., 42, 82788287, doi:10.1016/j.atmosenv.2008.07.038, 2008.

Grannas, A. M., Jones, A. E., Dibb, J., Ammann, M., Anastasio, C., Beine, H. J., Bergin, M., Bottenheim, J., Boxe, C. S., Carver, G., Chen, G., Crawford, J. H., Dominé, F., Frey, M. M., Guzmán, M. I., Heard, D. E., Helmig, D., Hoffmann, M. R., Honrath, R. E., Huey, L. G., Hutterli, M., Jacobi, H. W., Klán, P., Lefer, B., McConnell, J., Plane, J., Sander, R., Savarino, J., Shepson, P. B., Simpson, W. R., Sodeau, J. R., von Glasow, R., Weller, R., Wolff, E. W., and Zhu, T.: An overview of snow photochemistry: evidence, mechanisms and impacts, Atmos. Chem. Phys., 7, 43294373, doi:10.5194/acp-7-4329-2007, 2007.

Grosjean, D., van Cauwenberghe, K., Schmid, J. P., Kelley, P. E., and Pitts, J. N.: Identification of $\mathrm{C}_{3}-\mathrm{C}_{10}$ aliphatic dicarboxylic acids in airborne particulate matter, Environ. Sci. Technol., 12, 313-317, doi:10.1021/es60139a005, 1978.

Guilhermet, J., Preunkert, S., Voisin, D., Baduel, C., and Legrand, M.: Major 20th century changes of water-soluble humic-like substances (HULIS WS) aerosol over Europe inferred from Alpine ice cores, J. Geophys. Res. Atmos., 118, 3869-3878, doi:10.1002/jgrd.50201, 2013.

Hatakeyama, S., Ohno, M., Weng, J., Takagi, H., and Akimoto, H.: Mechanism for the formation of gaseous and particulate products from ozone-cycloalkene reactions in air, Environ. Sci. Technol., 21, 52-57, doi:10.1021/es00155a005, 1987.

Hoffmann, T., Bandur, R., Marggraf, U., and Linscheid, M.: Molecular composition of organic aerosols formed in the $\alpha$-pinene $/ \mathrm{O}_{3}$ reaction: implications for new particle formation processes, J. Geophys. Res., 103, 25569, doi:10.1029/98JD01816, 1998.

Hutterli, M. A., Bales, R. C., McConnell, J. R., and Stewart, R. W.: HCHO in Antarctic snow: preservation in ice cores and air-snow exchange, Geophys. Res. Lett., 8, 76-1-76-4, doi:10.1029/2001GL014256, 2002.
Janson, R. W.: Monoterpene emissions from Scots pine and Norwegian spruce, J. Geophys. Res., 98, 2839, doi:10.1029/92JD02394, 1993.

Kahnt, A., Behrouzi, S., Vermeylen, R., Safi Shalamzari, M., Vercauteren, J., Roekens, E., Claeys, M., and Maenhaut, W.: Oneyear study of nitro-organic compounds and their relation to wood burning in $\mathrm{PM}_{10}$ aerosol from a rural site in Belgium, Atmos. Environ., 81, 561-568, doi:10.1016/j.atmosenv.2013.09.041, 2013.

Kautzman, K. E., Surratt, J. D., Chan, M. N., Chan, A. W. H., Hersey, S. P., Chhabra, P. S., Dalleska, N. F., Wennberg, P. O., Flagan, R. C., and Seinfeld, J. H.: Chemical composition of gasand aerosol-phase products from the photooxidation of naphthalene, J. Phys. Chem. A, 114, 913-934, doi:10.1021/jp908530s, 2010.

Kawamura, K., Suzuki, I., Fujii, Y., and Watanabe, O.: Ice core record of fatty acids over the past 450 years in Greenland, Geophys. Res. Lett., 23, 2665-2668, doi:10.1029/96GL02428, 1996.

Kawamura, K., Yokoyama, K., Fujii, O., and Watanabe, O.: A Greenland ice core record of low molecular weight dicarboxylic acids, ketocarboxylic acids, and alpha-dicarbonyls: a trend from Little Ice Age to the present (1540 to 1989 AD), J. Geophys. Res., 106, 1331-1345, doi:10.1029/2000JD900465, 2001.

Kawamura, K., Izawa, Y., Mochida, M., and Shiraiwa, T.: Ice core records of biomass burning tracers (levoglucosan and dehydroabietic, vanillic and $p$-hydroxybenzoic acids) and total organic carbon for past 300 years in the Kamchatka Peninsula, Northeast Asia, Geochim. Cosmochim. Ac., 99, 317-329, doi:10.1016/j.gca.2012.08.006, 2012.

Kellerhals, T., Brütsch, S., Sigl, M., Knüsel, S., Gäggeler, H. W., and Schwikowski, M.: Ammonium concentration in ice cores - a new proxy for regional temperature reconstruction?, J. Geophys. Res.-Atmos., 115, D16123, doi:10.1029/2009JD012603, 2010.

Kim, K., Choi, W., Hoffmann, M. R., Yoon, H.-I., and Park, B.K.: Photoreductive dissolution of iron oxides trapped in ice and its environmental implications, Environ. Sci. Technol., 44, 4142 4148, doi:10.1021/es9037808, 2010.

Koch, S., Winterhalter, R., Uherek, E., Kolloff, A., Neeb, P., and Moortgat, G. K.: Formation of new particles in the gas-phase ozonolysis of monoterpenes, Atmos. Environ., 34, 4031-4042, doi:10.1016/S1352-2310(00)00133-3, 2000.

Komenda, M. and Koppmann, R.: Monoterpene emissions from Scots pine (Pinus sylvestris): field studies of emission rate variabilities, J. Geophys. Res., 107, ACH 1-1-ACH 1-13, doi:10.1029/2001JD000691, 2002.

Lacorte, S., Quintana, J., Tauler, R., Ventura, F., Tovar-Sánchez, A., and Duarte, C.: Ultra-trace determination of persistent organic pollutants in Arctic ice using stir bar sorptive extraction and gas chromatography coupled to mass spectrometry, J. Chromatogr A, 1216, 8581-8589, doi:10.1016/j.chroma.2009.10.029, 2009.

Largiuni, O., Udisti, R., Becagli, S., Traversi, R., Maggi, V., Bolzacchini, E., Casati, P., Uglietti, C., and Borghi, S.: Formaldehyde record from Lys glacier firn core, Monte Rosa massif (Italy), Atmos. Environ., 37, 3849-3860, doi:10.1016/S13522310(03)00474-6, 2003.

Lee, S., Baumann, K., Schauer, J. J., Sheesley, R. J., Naeher, L. P., Meinardi, S., Blake, D. R., Edgerton, E. S., Russell, A. G., and Clements, M.: Gaseous and particulate emissions from pre- 
scribed burning in Georgia, Environ. Sci. Technol., 39, 90499056, doi:10.1021/es0515831, 2005.

Legrand, M. and de Angelis, M.: Light carboxylic acids in Greenland ice: a record of past forest fires and vegetation emissions from the boreal zone, J. Geophys. Res. Atmos., 101, 4129-4145, doi:10.1029/95JD03296, 1996.

Legrand, M., de Angelis, M., Staffelbach, T., Neftel, A., and Stauffer, B.: Large perturbations of ammonium and organic acids content in the summit-Greenland Ice Core, fingerprint from forest fires?, Geophys. Res. Lett., 19, 473-475, doi:10.1029/91GL03121, 1992.

Legrand, M., Preunkert, S., Wagenbach, D., and Fischer, H.: Seasonally resolved Alpine and Greenland ice core records of anthropogenic $\mathrm{HCl}$ emissions over the 20th century, J. Geophys. Res., 107, 4139, doi:10.1029/2001JD001165, 2002.

Legrand, M., Preunkert, S., Wagenbach, D., Cachier, H., and Puxbaum, H.: A historical record of formate and acetate from a high-elevation Alpine glacier: implications for their natural vs. anthropogenic budgets at the European scale, J. Geophys. Res. Atmos., 108, 4788, doi:10.1029/2003JD003594, 2003.

Legrand, M., Preunkert, S., Schock, M., Cerqueira, M., KasperGiebl, A., Afonso, J., Pio, C., Gelencsér, A., and DombrowskiEtchevers, I.: Major 20th century changes of carbonaceous aerosol components (EC, WinOC, DOC, HULIS, carboxylic acids, and cellulose) derived from Alpine ice cores, J. Geophys. Res., 112, D23S11, doi:10.1029/2006JD008080, 2007.

Legrand, M., Preunkert, S., Jourdain, B., Guilhermet, J., Faïn, X., Alekhina, I., and Petit, J. R.: Water-soluble organic carbon in snow and ice deposited at Alpine, Greenland, and Antarctic sites: a critical review of available data and their atmospheric relevance, Clim. Past, 9, 2195-2211, doi:10.5194/cp-9-2195-2013, 2013.

Li, X., Qin, D., and Zhou, H.: Organic acids: differences in ice core records between Glacier 1, Tianshan, China and the polar areas, Chinese Sci. Bull., 46, 80-83, doi:10.1007/BF03183216, 2001.

Martin, R. S., Villanueva, I., Zhang, J., and Popp, C. J.: Nonmethane hydrocarbon, monocarboxylic acid, and low molecular weight aldehyde and ketone emissions from vegetation in central New Mexico, Environ. Sci. Technol., 33, 2186-2192, doi:10.1021/es980468q, 1999.

Mayewski, P. A., Lyons, W. B., Spencer, M. J., Twickler, M., Dansgaard, W., Koci, B., Davidson, C. I., and Honrath, R. E.: Sulfate and nitrate concentrations from a South Greenland ice core, Science, 232, 975-977, doi:10.1126/science.232.4753.975, 1986.

McConnell, J. R., Edwards, R., Kok, G. L., Flanner, M. G., Zender, C. S., Saltzman, E. S., Banta, J. R., Pasteris, D. R., Carter, M. M., and Kahl, J. D. W.: 20th-century industrial black carbon emissions altered Arctic climate forcing, Science, 317, 1381-1384, doi:10.1126/science.1144856, 2007.

MeteoSwiss, Federal Office of Meteorology and Climatology, Climate trends in Switzerland, available at: http://www.meteoswiss.admin.ch/home/climate/present-day/ climate-trends.html\#ths200m0;south;year;1864-smoother, last access: 30 August, 2015.

Müller-Tautges, C., Eichler, A., Schwikowski, M., and Hoffmann, T.: A new sensitive method for the quantification of glyoxal and methylglyoxal in snow and ice by stir bar sorptive extraction and liquid desorption-HPLC-ESI-MS, Anal. Bioanal. Chem., 406, 2525-2532, doi:10.1007/s00216-014-7640-z, 2014.
Nishino, N., Arey, J., and Atkinson, R.: Formation Yields of Glyoxal and Methylglyoxal from the Gas-Phase OH RadicalInitiated Reactions of Toluene, Xylenes, and Trimethylbenzenes as a Function of $\mathrm{NO}_{2}$ Concentration, J. Phys Chem. A, 114, 10140-10147, doi:10.1021/jp105112h, 2010.

O’Dowd, C. D., Aalto, P., Hmeri, K., Kulmala, M., and Hoffmann, T.: Aerosol formation: atmospheric particles from organic vapours, Nature, 416, 497-498, doi:10.1038/416497a, 2002.

Pavlova, P. A., Schmid, P., Bogdal, C., Steinlin, C., Jenk, T. M., and Schwikowski, M.: Polychlorinated biphenyls in glaciers. 1. Deposition history from an Alpine ice core, Environ. Sci. Technol., 48, 7842-7848, doi:10.1021/es5017922, 2014.

Pérez-Rial, D., Peñuelas, J., López-Mahía, P., and Llusià, J.: Terpenoid emissions from Quercus robur, a case study of Galicia (NW Spain), J. Environ. Monit., 11, 1268, doi:10.1039/b819960d, 2009.

Pezzatti, G. B., Bajocco, S., Torriani, D., and Conedera, M.: Selective burning of forest vegetation in Canton Ticino (southern Switzerland), Plant Biosyst., 143, 609-620, doi:10.1080/11263500903233292, 2009.

Pezzatti, G. B., Reinhard, M., and Conedera, M.: Swissfire: the new Swiss forest fire database, Swiss For. J., 161, 465-469, doi:10.3188/szf.2010.0465, 2010.

Preunkert, S. and Legrand, M.: Towards a quasi-complete reconstruction of past atmospheric aerosol load and composition (organic and inorganic) over Europe since 1920 inferred from Alpine ice cores, Clim. Past, 9, 1403-1416, doi:10.5194/cp-91403-2013, 2013.

Preunkert, S., Legrand, M., and Wagenbach, D.: Sulfate trends in a Col du Dome French Alps ice core: a record of anthropogenic sulfate levels in the European midtroposphere over the twentieth century, J. Geophys. Res. Atmos., 106, 31991-32004, doi:10.1029/2001JD000792, 2001.

Preunkert, S., Wagenbach, D., and Legrand, M.: A seasonally resolved alpine ice core record of nitrate: comparison with anthropogenic inventories and estimation of preindustrial emissions of NO in Europe, J. Geophys. Res. Atmos., 108, 4681, doi:10.1029/2003JD003475, 2003.

Rodríguez, E., Fernández, G., Ledesma, B., Álvarez, P., and Beltrán, F. J.: Photocatalytic degradation of organics in water in the presence of iron oxides: influence of carboxylic acids, Appl. Catal. B-Environ., 92, 240-249, doi:10.1016/j.apcatb.2009.07.013, 2009.

Schweizerische Gesamtenergiestatistik: Schweizerische Eidgenossenschaft, Bundesamt für Energiewirtschaft, available at: http://www.bfe.admin.ch/themen/00526/00541/00542/ 00631/index.html?dossier_id=00763\&lang=en (last access: 30 August 2015), 2012.

Schwikowski, M., Brütsch, S., Gäggeler, H. W., and Schotterer, U.: A high-resolution air chemistry record from an Alpine ice core: fiescherhorn glacier, Swiss Alps, J. Geophys. Res., 104, 1370913719, doi:10.1029/1998JD100112, 1999.

Schwikowski, M., Barbante, C., Doering, T., Gaeggeler, H. W., Boutron, C., Schotterer, U., Tobler, L., van de Velde, K., Ferrari, C., Cozzi, G., Rosman, K., and Cescon, P.: Post-17thcentury changes of European lead emissions recorded in highaltitude Alpine snow and ice, Environ. Sci. Technol., 38, 957964, doi:10.1021/es034715o, 2004. 
Simoneit, B. R. T.: Biomass burning - a review of organic tracers for smoke from incomplete combustion, Appl. Geochem., 17, 129162, doi:10.1016/S0883-2927(01)00061-0, 2002.

Simpson, I. J., Akagi, S. K., Barletta, B., Blake, N. J., Choi, Y., Diskin, G. S., Fried, A., Fuelberg, H. E., Meinardi, S., Rowland, F. S., Vay, S. A., Weinheimer, A. J., Wennberg, P. O., Wiebring, P., Wisthaler, A., Yang, M., Yokelson, R. J., and Blake, D. R.: Boreal forest fire emissions in fresh Canadian smoke plumes: $\mathrm{C}_{1}-\mathrm{C}_{10}$ volatile organic compounds (VOCs), $\mathrm{CO}_{2}, \mathrm{CO}, \mathrm{NO}_{2}$, NO, $\mathrm{HCN}$ and $\mathrm{CH}_{3} \mathrm{CN}$, Atmos. Chem. Phys., 11, 6445-6463, doi:10.5194/acp-11-6445-2011, 2011.

Staffelbach, T., Neftel, A., Stauffer, B., and Jacob, D.: A record of the atmospheric methane sink from formaldehyde in polar ice cores, Nature, 349, 603-605, doi:10.1038/349603a0, 1991.

Stemmler, K., Bugmann, S., Buchmann, B., Reimann, S., and Staehelin, J.: Large decrease of VOC emissions of Switzerland's car fleet during the past decade: results from a highway tunnel study, Atmos. Environ., 39, 1009-1018, doi:10.1016/j.atmosenv.2004.10.010, 2005.

Stephanou, E. G. and Stratigakis, N.: Oxocarboxylic and $\alpha, \omega-$ dicarboxylic acids: photooxidation products of biogenic unsaturated fatty acids present in urban aerosols, Environ. Sci. Technol., 27, 1403-1407, doi:10.1021/es00044a016, 1993.

van de Velde, K., Boutron, C. F., Ferrari, C. P., Moreau, A., Delmas, R. J., Barbante, C., Bellomi, T., Capodaglio, G., and Cescon, P.: A two hundred years record of atmospheric cadmium, copper and zinc concentrations in high altitude snow and ice from the French-Italian Alps, Geophys. Res. Lett., 27, 249-252, doi:10.1029/1999GL010786, 2000.
Villa, S., Negrelli, C., Maggi, V., Finizio, A., and Vighi, M.: Analysis of a firn core for assessing POP seasonal accumulation on an Alpine glacier, Ecotox. Environ. Safe., 63, 17-24, doi:10.1016/j.ecoenv.2005.05.006, 2006.

Wang, J., Yao, T., Xu, B., Wu, G., and Xiang, S.: Formate and acetate records in the Muztagata ice core, Northwest Tibetan Plateau, Chinese Sci. Bull., 49, 1620, doi:10.1007/BF03184132, 2004.

Wang, X., Xu, B., Kang, S., Cong, Z., and Yao, T.: The historical residue trends of DDT, hexachlorocyclohexanes and polycyclic aromatic hydrocarbons in an ice core from Mt. Everest, central Himalayas, China, Atmos. Environ., 42, 6699-6709, doi:10.1016/j.atmosenv.2008.04.035, 2008.

Yu, J., Cocker, D. R., Griffin, R. J., Flagan, R. C., and Seinfeld, J. H.: Gas-phase ozone oxidation of monoterpenes: gaseous and particulate products, J. Atmos. Chem., 34, 207-258, doi:10.1023/A:1006254930583, 1999.

Zhang, Y. Y., Müller, L., Winterhalter, R., Moortgat, G. K., Hoffmann, T., and Pöschl, U.: Seasonal cycle and temperature dependence of pinene oxidation products, dicarboxylic acids and nitrophenols in fine and coarse air particulate matter, Atmos. Chem. Phys., 10, 7859-7873, doi:10.5194/acp-10-7859-2010, 2010. 